\title{
DERMATOLOGY AND TELEMEDICINE: GOALS, ADVANTAGES AND DISADVANTAGES
}

Dvornikov AS, Minkina OV, Grebenshchikova EG $\bowtie$, Vvedenskaya EV, Mylnikova IS

Pirogov Russian National Research Medical University, Moscow, Russia

COVID-19 pandemic has made changes to conventional health care. In view of the need for "social distancing", telemedicine services became most in demand, which constituted a reform of the previous doctor-patient relationship format; dermatology was no exception. Increased use of teledermatology (TD) all over the world elevated the relevance of the set of challenges related to teledermatology potential and limits, particularly in the light of the expectations of the technology broader application during the post-pandemic period. The review addresses the issues related to accounting for quality of health care, understanding the social and humanitarian context of TD, as well as the impact on professional education.

Keywords: COVID-19, telemedicine, dermatology, teledermatology, bioethics

Author contribution: Dvornikov AS — study concept and design, manuscript editing; Minkina OV — study concept and design, manuscript writing; Grebenshchikova EG — study concept and design, manuscript writing; Vvedenskaya EV — literature analysis, text writing; Mylnikova IS — literature analysis, text writing.

$\triangle$ Correspondence should be addressed: Elena G. Grebenshchikova

Ostrovitianova, 1, Moscow, 117997; aika45@ya.ru

Received: 17.08.2021 Accepted: 27.08.2021 Published online: 31.08.2021

DOI: $10.24075 /$ brsmu.2021.041

\section{ДЕРМАТОЛОГИЯ И ТЕЛЕМЕДИЦИНА: ЦЕЛИ, ПРЕИМУЩЕСТВА И НЕДОСТАТКИ}

\author{
А. С. Дворников, О. В. Минкина, Е. Г. Гребенщикова $\bowtie$ Е. В. Введенская, И. С. Мыльникова
}

Российский национальный исследовательский медицинский университет имени Н. И. Пирогова, Москва, Россия

\begin{abstract}
Пандемия COVID-19 внесла изменения в традиционное медицинское обслуживание. В связи с необходимостью «социального дистанцирования» особенно востребованными стали услуги телемедицинской помощи, что изменило прежний формат взаимоотношений врача и пациента; дерматология не стала исключением. Активное использование теледерматологии (ТД) во всем мире актуализировало комплекс проблем, связанных с ее возможностями и недостатками, особенно в свете ожиданий более широкого применения этой технологии в постпандемический период. В обзоре освещены вопрось качества оказания медицинской помощи, понимания социогуманитарных контекстов развития ТД и последствий для сферы профессионального образования.
\end{abstract}

Ключевые слова: COVID-19, дерматология, телемедицина, теледерматология, биоэтика

Вклад авторов: А. С. Дворников - концепция и дизайн исследования, редактирование статьи; О. В. Минкина - концепция и дизайн исследования, написание статьи; Е. Г. Гребенщикова - концепция и дизайн исследования, написание статьи; Е. В. Введенская - анализ источников, написание текста; И. С. Мыльникова - анализ источников, написание текста.

$\checkmark$ Для корреспонденции: Елена Георгиевна Гребенщикова ул. Островитянова, д. 1, г. Москва, 117997; aika45@уа.ru

Статья получена: 17.08.2021 Статья принята к печати: 27.08.2021 Опубликована онлайн: 31.08.2021

DOI: 10.24075/vrgmu.2021.041

\section{Teledermatology as a section of telemedicine}

Telemedicine (TM) is an information and communication technology for provision of health care and medical services, based on remote data communication aimed at diagnosis and treatment of the disorders, clinical and laboratory assessment data analysis, and remote patient monitoring. The technology can also be used as a professional educational resource ("remote healing and specialized learning"). In the Russian Federation, the term TM was established in 2001 in the project of Coordination Council for TM of the Ministry of Health of the Russian Federation, the Concept of TM Technology Development in the Russian Federation. In 2017, the concept of "telemedicine technology" was introduced at the federal legislative level, which included two spheres of use: remote care provision and electronic flow of medical documents [1]. Teledermatology (TD) involves the use of digital technology making it possible to freely advise patients with disorders of skin or it's appendages regardless of the distance and time zone; analyze the results of various types of studies, including dermatoscopy images, by data transmission performed at a time appropriate both for the patient and the physician; run remote collegiate conferences in the situations, where the expert opinion is required.
Conventional TD technologies are as follows: asynchronous TD, or SAF (Store-and-Forward), which involves time delay estimation of spatially dispersed images or any other supplementary data; synchronous TD, or RT-TD (real-time teledermatology), involving real-time video consultations; hybrid model (SAF + RT-TD) and mobile TD [2]. Earlier, TD most often involved the store-and-forward models. The number of interactive RT-TD communication significantly increased during the COVID-19 pandemic. Survey about the effects of the pandemic on TD performed in May and June 2020, involving 591 dermatology practitioners being the AAD (American Academy of Dermatology) members, showed that only $14.1 \%$ of respondents used TD before the pandemic compared with 96.9\% after the COVID-19 emergence; 58.0\% of dermatologists assumed they would use TD in the future regardless of the epidemiological situation; $72.0 \%$ of physicians rated hybrid model as the most accurate [3].

According to a number of researchers, TD and face-to-face consultations have comparable diagnostic accuracy [4; 5]. The real-time work has certain definite advantages, such as firsthand opportunity to ask clarifying questions, resolve disputes and explain obscure points in a timely manner, control patient's understanding of the recommendations received. However, the quality of video used in RT-TD is usually lower than the 
quality of static images used in SAF, particularly with respect to teledermatoscopy and ultrastructural analysis of features in melanocytic, vascular or keratinized cutaneous neoplasms.

In 2021, the results of 2632 TD consultations, conducted from 16.03.2020 to 01.05.2020, were published: SAF accounted for $36.2 \%$ consultations, and RT-TD accounted for $63.8 \%$. A total of $54.2 \%$ medical service providers preferred synchronous consultations for the reason of benefits provided by face-to-face doctor-patient communication. No preference was expressed for selection of TD modification for initial visit, however, $66.7 \%$ of medical service providers selected RT-TD for return visit; $87.5 \%$ preferred synchronous consultations for patients with connective tissue diseases and immunobullous disorders, as well as for patients receiving biological therapy [6]. TD modification with greater differential diagnosis variability in relation to particular patient was determined: with the use of RT-TD, the number of diagnoses varied in the range of 1-5; with the use of SAF, it varied in the range of 1-3. RT-TD provides conditions as close as possible to in-person visit, therefore the doctor-patient relationship can deviate from simple analysis of actual data, which expands differential diagnosis and, in turn, affects the diagnosis accuracy.

TD could prove indispensable for remote in-patient assessment given insufficient staffing of hospitals all over the world with dermatologists. The study of diagnostic impressions and therapeutic recommendations in facility-based clinician, external dermatologist (ED) and SAF teledermatologist (SAF-TD) involving 100 patients revealed no substantial differences in the diagnosis accuracy and subsequent prescribing therapy between facility-based dermatogist and SAF-TD: ED advice resulted in diagnosis change in $50.9 \%$ of cases, and SAF-TD in $54.7 \%$ of cases respectively; ED changed systemic therapy in $41.5 \%$ of cases, and SAF consultations resulted in treatment adjustment in $47.2 \%$ of cases. When comparing ED and SAF-TD, diagnostic complete and partial agreement were $52.8 \%$ and $84.9 \%$, respectively; systemic therapy agreement was reached in $77.4 \%$ of cases [7].

Mobile TD and teledermatoscopy (TDS) include the expanded specialized TM services allowing one to send and receive data via smartphones and appropriate applications. Survey of dermatology practitioners in Australia showed that more than $50 \%$ of respondents sent and received clinical images on their smartphones at least weekly; this value in young professionals and interns was 89\% [8].

The researchers consider the opportunity to significantly improve and quicken access to specialized health care in remote regions understuffed with specialists the main advantage of TD, making it possible to eliminate health inequalities. Moreover, TD can improve access to treatment in patients, who face certain social and economic barriers: childcare periods; decreased mobility; severe social anxiety; complex work schedule [9]. In these cases, there is particular interest in the use of asynchronous TD: the physician performes assessment of images, video and examination results without any in-person visits, and usually spends less time on dealing with each individual case, which can be considered an advantage given the shortage of professionals. It is assumed, however, that the patient would not deal with lack of attention from the doctor during the remote consultation. In a survey of 52 patients with acne, who used TM services during the pandemic, 92.3\% rated the attention paid by the dermatologist regarding their disease as favourable; $86.5 \%$ of patients were satisfied with the duration of the visit [10].

Moreover, at the level of general practitioner, TD enables screening for various dermatological diseases assigning the patients an urgency category ("immediate" and "delayed") for further specialized care provision. Simple techniques allowing the patients to improve the quality of skin lesion images to be used during the further general therapeutic SAF consultations themselves have been proposed: "tape dermatoscopy" technique (immersion fluid placed on the lesion, covering the lesion with transparent adhesive tape, recording the image with a smartphone) [11]; "drop TD" technique (applying clear alcohol-based sanitizer with subsequent recording of the image using no adhesive tape) [12].

\section{Limitations of teledermatology}

Although the potential benefits of TM are obvious, and dermatology, being a discipline based a lot on the use of images, seems to be the most appropriate area of medicine for the use of TM, the widespread adoption of TM in this area meets serious resistance from healthcare professionals. For example, poor stream video quality or sharing poor-qiality image files can complicate the doctor-patient relationship and result in various errors. Images of affected body regions having insufficient resolution, as well as restricted photographing private parts covered with rashes, could be a serious obstacle to morphological elements assessment, analysis of the disease development, diagnosis, and determining the required scope of the examination.

When working in the TD format, there could not only be technical difficulties, such as data networks integration, as well as the issues related to licensing of TM systems, combining TD data with electronic patient records, and financial reporting, but also ethical dilemmas related to confidentiality of the information provided, quality control in healthcare, and regulation of the subsequent physician's liability being the result of "longdistance" examination performed by specialist, even in case the physician and the examined person come from different jurisdictions [13].

The loss of real-life communication between the physician and the patient is one the major ethical issues related to TD. During the in-person consultation, dermatologist performs general and specialized instrumental examination of the patient, e.g. luminescence-based examination, diascopy, etc., helping to distinguish dozens of disorders and establish the presumptive diagnosis, inter alia based on the patient's scent, skin peeling pattern, tactile sensation in palpation, and staining of the skin with special dyes. TD consultation deprives the physician of this possibility. The vast majority of patients reported satisfaction with the quality of healthcare services during the study aimed to assess the patients' perception of technical expertise on the use of synchronous TM during the COVID-19 outbreak. However, $68.7 \%$ of patients pointed out they would prefer an in-person consultation for their next visit rather than virtual consultation [14].

Despite years of efforts to implement TD and TDS for skin cancer screening [15], as the pandemic continued its progress, it became apparent that extended remote followup, delayed face-to-face assessment and surgery can result in exacerbation of chronic disorders, and delayed cancer detection and treatment. One notable limitation of TDS is inability to perform full examination of skin on a regular basis. Since the incidence of melanoma has increased more rapidly compared to any other cancer type during the pre-pandemic period [16], TDS innovations can exacerbate this dangerous trend [17] and result in reduced early diagnosis and increased mortality. The impact of time to definitive stage I-III melanoma surgery on overall survival was assessed by using the National 
Cancer Database (153,218 patients) data [18]. Multivariate analysis of cases in all stages showed that the patients who were treated between 90 and 119 days, and more than 119 days after biopsy, had a higher risk for mortality compared with those treated within 30 days of biopsy. It should be reminded that survival rate in patients whose melanoma is detected early reaches 99\% [19]. The intra-group stage-based analysis performed during this study revealed higher mortality risk in patients with stage I treated more than 30 days after biopsy; surgical timing did not affect survival in stages II and III.

Inability to perform procedures is one more notable limitation of TD [20]. It was recognized in the beginning of the pandemic [21], which reflected the situation in other areas of medicine, where the need for various manipulations being a difficult if not impossible task for a layman at home had become a problem.

Thus, despite the enthusiasm related to access to dermatological care, clearly understandable during the pandemic, TD still cannot compete with face-to-face medical consultations and can be used in the situations with no alternatives by fully qualified dermatologists. Moreover confirming the professional competence of the physician, usually contacted by patients from anywhere in the world, also becomes a problem.

It is also important to point out that TD cannot fully address the problem of access to health care services, since not every patient has the required level of literacy, as well as access to broadband Internet and equipment for photography and videoconferencing. This problem is urgent for many countries and regions all over the world. Thus, in India, where the shortage of dermatologists is particularly acute, TD has been treated as a promising opportunity to revolutionize dermatological care during the COVID-19 crisis. However, availability of stable Internet connection and technological illiteracy have become a serious obstacle for widespread adoption of TD in this country [22].

\section{Teledermatology and specialists' education}

TM in the "doctor-to-doctor" format is also considered an important educational tool for improving professional competence in medical students, dermatology residents, and professionals with little practical experience [23]. Some professionals believe that integration of TD in residency training programs could have a significant impact on the dermatologists' professional competence formation.

Furthermore, such online education technologies as video lectures, interactive teleconferencing, virtual microscopy, and clinical simulation have become very popular among medical students and resident physicians, and have proved to be effective; these technologies could constitute a significant proportion of self-directed clinical education and enable objectification of the subsequent knowlege assessment. According to the survey of dermatology residency program directors conducted in 2016, 69\% of respondents were interested in potentially incorporating TM into their curriculum [24].

However, to practice to the fullest extent, dermatologist should have not only deep theoretical knowledge and large visual memory storage capacity, but also possess various surgical and procedural skills. To date, online broadcasting of surgery performed by highly qualified professionals is quite common. However, despite the attractiveness of TM, productive TM applicability in students, resident physicians and experienced physicians differs [25]. The experience of Netherlands and Australia, where TD is integrated into health system as an important supplement to conventional dermatological care, and the electronic records are accessible to all users of the system, is a successful model of using new technology [26].

\section{Teledermatology in the context of healthcare digitalization}

The use if TM in dermatology is a part of a broader trend of health care digitalization, improvement of health care capacity due to strong deployment of information and communication technologies at different levels of the health system organization, as well as in extra-clinical sphere as a result of rapid development of the mobile health (mHealth) market.

The clinical decision support programmes based on deep learning and artificial intelligence (Al) technologies are being vigorously developed. The results of the diagnostic performance comparative analysis performed in 2020 in human subjects and ResNet34 system, being a convolutional neural network (CNN), involved construction of contemporary computer vision models in multiple settings. In an effort to identify optimal conditions for further beneficial humancomputer collaboration, a total of 302 physicians from 41 countries were surveyed: board-certified dermatologists accounted for $56.0 \%$, dermatology residents for $25.5 \%$, and general practitioners for $12.6 \%$. During testing with the use of benchmark test set (1412 dermoscopic images) of various cutaneous neoplasms (melanoma, basal cell carcinoma, actinic keratosis, intraepithelial carcinoma, melanocytic nevi, benign keratinized neoplasms, dermatofibroma, vascular lesions), the ResNet34 sensitivity in all categories of images was $77.7 \%$, and the accuracy was $80.3 \%$. ResNet34 was most beneficial in assessment of such pigmented lesions as actinic keratosis and intraepithelial carcinoma compared to other types of lesions. Medical decision-making support with Al-based multiclass probabilities improved the accuracy of human raters' work from $63.6 \%$ to $77.0 \%$, however, it was of little effect when predicting lesion malignancy in laboratory settings. According to the authors, the Al-based computer system performance should be tested not only in real world, but also by the target user. These systems should not be recommended as standalone devices for widespread use [27].

It is quite clear that Al-based diagnostic systems would not replace dermatologists in the near future. However, significance of such systems for diagnosis and increased provision of care cannot be denied. Both physicians and patients aware of the advantages and limitations of health care technological innovation given the specificity of dermatology as the field of medicine should be ready to use the Al-based technologies.

\section{Conclusion}

The experience of the TD broader use during the pandemic revealed both TD potential and limitations, many of which had been previously discussed by the specialists. It is obvious that most of the issues would gradually be resolved due to new technology development (for example, image quality improvement), development of ethical standards and legal norms (issues of confidentiality protection), bridging the digital divide between the generations, active incorporation of TD programmes into medical education, and would encourage the further development of this field of medicine. However, the development of TD in a socially responsible and patient-oriented manner requires understanding both dermatological care peculiarities (the need for visual and instrumental examination, as well as for face-to-face contact) and the features of doctorpatient relationship, which largely determine the diagnosis and treatment success. 
1. Prikaz Ministerstva zdravohranenija RF ot 30.11.2017 \# 965n «Ob utverzhdenii porjadka organizacii i okazanija medicinskoj pomoshhi s primeneniem telemedicinskih tehnologiy». Dostupno po ssylke: http://www.pravo.gov.ru. Russian.

2. Kanthraj GR. Teledermatology: Its role in dermatosurgery. J Cutan Aesthet Surg. 2008; 1 (2): 68-74. PubMed PMID: 20300347.

3. Kennedy J, Arey S, Hopkins Z, Tejasvi T, Farah R, Secrest AM, et al. Dermatologist perceptions of teledermatology implementation and future use after COVID-19 demographics, barriers, and insights. JAMA Dermatol. 2021; 157 (5): 595-7. PubMed PMID: 33787839. DOI: 10.1001/jamadermatol.2021.0195.

4. Moreno-Ramirez D, Argenziano G. Teledermatology and mobile applications in the management of patients with skin lesions. Acta Derm Venereol. 2017; Suppl 218: 31-35. PubMed PMID: 28676881.

5. Lee JJ, English JC III. Teledermatology: A review and update. Am J Clin Dermatol. 2018; 19 (2): 253-60. PubMed PMID: 28871562.

6. Kazi R, Evankovich MR, Liu R, Liu A, Moorhead A, Ferris L K, et al. Utilization of asynchronous and synchronous teledermatology in a large health care system during the COVID-19 pandemic. Telemedicine and e-Health. 2021; 27 (7): 771-7. PubMed PMID: 33074786.

7. Keller JJ, Johnson JP, Latour E. Inpatient teledermatology: diagnostic and therapeutic concordance among a hospitalist, dermatologist, and teledermatologist using store-and-forward teledermatology. J Am Acad Dermatol. 2020; 82 (5): 1262-7. PubMed PMID: 31972258.

8. Abbott LM, Magnusson RS, Gibbs E, Smith SD. Smartphone use in dermatology for clinical photography and consultation: Current practice and law. Australas J Dermatol. 2018 May; 59 (2): 101-7. PubMed PMID: 28247404.

9. Pulsipher KJ, Presley CL, Rundle CW, Rietcheck HR, Millitelo M, Dellavalle RP. Teledermatology application use in the COVID-19 era. Dermatology Online Journal. 2020; 26 (12). PubMed PMID: 33423415.

10. Ruggiero A, Megna M, Annunziata MC, Abategiovanni L, Scalvenzi M, Tajani A, et al. Teledermatology for acne during COVID-19: high patients' satisfaction in spite of the emergency. J Eur Acad Dermatol Venereol. 2020; 34 (11): e662-e663. PubMed PMID: 32534472.

11. Blum A, Giacomel J. «Tape dermatoscopy»: constructing a lowcost dermatoscope using a mobile phone, immersion fluid and transparent adhesive tape. Dermatol Pract Concept. 2015; 5 (2): 87-93. PubMed PMID: 26114061.

12. Kaliyadan F, Jayasree P, Ashique KT. Drop dermoscopy for teledermatology. Journal of the American Academy of Dermatology. 2021. 84 (1): e25-e26. PubMed PMID: 32771542.

13. Adelekun A, Sager MA, Lipoff JB. Bridging the divide, virtually: ethics of teledermatology. Dermatoethics. Contemporary ethics and professionalism in dermatology. Springer Nature Switzerland AG. 2021: 59-58

14. Pearlman RL, Le PB, Brodell RT, Nahar VK. Evaluation of patient

\section{Литература}

1. Приказ Министерства здравохранения РФ от 30.11 .2017 № 965н «Об утверждении порядка организации и оказания медицинской помощи с применением телемедицинских технологий». Доступно по ссылке: http://www.pravo.gov.ru.

2. Kanthraj GR. Teledermatology: Its role in dermatosurgery. J Cutan Aesthet Surg. 2008; 1 (2): 68-74. PubMed PMID: 20300347.

3. Kennedy J, Arey S, Hopkins Z, Tejasvi T, Farah R, Secrest AM, et al. Dermatologist perceptions of teledermatology implementation and future use after COVID-19 demographics, barriers, and insights. JAMA Dermatol. 2021; 157 (5): 595-7. PubMed PMID: 33787839. DOI: 10.1001/jamadermatol.2021.0195.

4. Moreno-Ramirez D, Argenziano G. Teledermatology and mobile applications in the management of patients with skin lesions. Acta Derm Venereol. 2017; Suppl 218: 31-35. PubMed PMID: 28676881.

5. Lee JJ, English JC III. Teledermatology: A review and update. Am attitudes towards the technical experience of synchronous teledermatology in the era of COVID-19. Arch Dermatol Res. 2021. 5:1-4. PubMed PMID: 33403572.

15. Kroemer S, Frühauf J, Campbell TM, Massone C, Schwantzer G, Soyer HP, et al. Mobile teledermatology for skin tumour screening: diagnostic accuracy of clinical and dermoscopic image teleevaluation using cellular phones. Br J Dermatol. 2011; 164: 9739. PubMed PMID: 21219286.

16. Okhovat JP, Beaulieu D, Tsao H, Halpern AC, Michaud DS, Shaykevich S, et al. The first 30 years of the American academy of dermatology skin cancer screening program: 1985-2014. J Am Acad Dermatol. 2018; 79: 884-91. PubMed PMID: 30057360.

17. Rustad AM, Lio PA.. Pandemic pressure: teledermatology and health care disparities. JPatient Exp. 2021; 8: 2374373521996982. PubMed PMID: 34179385.

18. Conic RZ, Cabrera Cl, Khorana AA, Gastman BR. Determination of the impact of melanoma surgical timing on survival using the National Cancer Database. J Am Acad Dermatol. 2018; 78 (1): 40-46.e7. PMID: 29054718.

19. American Cancer Society. Cancer Facts and Figures. January 8, 2021. Available from: https://www.cancer.org/content/dam/ cancerorg/research/cancer-facts-and-statistics/annual-cancerfacts-and-figures/2020/cancer-facts-and-figures-2020.pdf.

20. Farr MA, Duvic M, Joshi TP. Teledermatology during COVID-19: an updated review. American Journal of Clinical Dermatology. 2021; Apr 9: 1-9. PubMed PMID: 33835345.

21. Perkins S, Cohen JM, Nelson CA, Bunick CG. Teledermatology in the era of COVID-19: experience of an academic department of dermatology. Journal of the American Academy of Dermatology. 2020; 83 (1): e43-e44. PubMed PMID: 32305442.

22. Ashique KT, Kaliyadan F. Teledermatology in the wake of COVID-19 scenario: An Indian perspective. Indian Dermatology Online Journal. 2020; 11 (3): 301. PubMed PMID: 32695684.

23. Boyers LN, Schultz A, Baceviciene R, Blaney S, Marvi N, Dellavalle $\mathrm{RP}$, et al. Teledermatology as an educational tool for teaching dermatology to residents and medical students. Telemedicine and e-Health. 2015; 21 (4): 312-4. PubMed PMID: 25635528.

24. Wanat KA, Newman S, Finney KM, Kovarik CL, Lee I. Teledermatology education: current use of teledermatology in US residency programs. J Grad Med Educ. 2016; 8 (2): 286-7. PubMed PMID: 27168912.

25. Jones VA, Clark KA, Puyana C, Tsoukas MM. Rescuing medical education in times of COVID-19. Clin Dermatol. 2021; 39(1): 33-4.

26. Tensen E, Van Der Heijden JP, Jaspers MWM, Witkamp L. Two decades of teledermatology: current status and integration in national healthcare systems. Curr Dermatol Rep. 2016; 5 (2): 96-104. PubMed PMID: 27182461.

27. Tschandl P, Rinner C, Apalla Z, Argenziano G, Codella N, Halpern A, et al. Human-computer collaboration for skin cancer recognition. Nature Medicine. 2020; 26 (8): 1229-34. PubMed PMID: 32572267.

J Clin Dermatol. 2018; 19 (2): 253-60. PubMed PMID: 28871562. 6. Kazi R, Evankovich MR, Liu R, Liu A, Moorhead A, Ferris L K, et al. Utilization of asynchronous and synchronous teledermatology in a large health care system during the COVID-19 pandemic. Telemedicine and e-Health. 2021; 27 (7): 771-7. PubMed PMID: 33074786.

7. Keller JJ, Johnson JP, Latour E. Inpatient teledermatology: diagnostic and therapeutic concordance among a hospitalist, dermatologist, and teledermatologist using store-and-forward teledermatology. J Am Acad Dermatol. 2020; 82 (5): 1262-7. PubMed PMID: 31972258.

8. Abbott LM, Magnusson RS, Gibbs E, Smith SD. Smartphone use in dermatology for clinical photography and consultation: Current practice and law. Australas J Dermatol. 2018 May; 59 (2): 101-7. PubMed PMID: 28247404. 
9. Pulsipher KJ, Presley CL, Rundle CW, Rietcheck HR, Millitelo M, Dellavalle RP. Teledermatology application use in the COVID-19 era. Dermatology Online Journal. 2020; 26 (12). PubMed PMID: 33423415.

10. Ruggiero A, Megna M, Annunziata MC, Abategiovanni L, Scalvenzi M, Tajani A, et al. Teledermatology for acne during COVID-19: high patients' satisfaction in spite of the emergency. J Eur Acad Dermatol Venereol. 2020; 34 (11): e662-e663. PubMed PMID: 32534472

11. Blum A, Giacomel J. "Tape dermatoscopy»: constructing a lowcost dermatoscope using a mobile phone, immersion fluid and transparent adhesive tape. Dermatol Pract Concept. 2015; 5 (2): 87-93. PubMed PMID: 26114061.

12. Kaliyadan F, Jayasree $P$, Ashique KT. Drop dermoscopy for teledermatology. Journal of the American Academy of Dermatology. 2021. 84 (1): e25-e26. PubMed PMID: 32771542.

13. Adelekun A, Sager MA, Lipoff JB. Bridging the divide, virtually: ethics of teledermatology. Dermatoethics. Contemporary ethics and professionalism in dermatology. Springer Nature Switzerland AG. 2021: 59-58

14. Pearlman RL, Le PB, Brodell RT, Nahar VK. Evaluation of patient attitudes towards the technical experience of synchronous teledermatology in the era of COVID-19. Arch Dermatol Res. 2021. 5:1-4. PubMed PMID: 33403572

15. Kroemer S, Frühauf J, Campbell TM, Massone C, Schwantzer G, Soyer HP, et al. Mobile teledermatology for skin tumour screening: diagnostic accuracy of clinical and dermoscopic image teleevaluation using cellular phones. Br J Dermatol. 2011; 164: 9739. PubMed PMID: 21219286.

16. Okhovat JP, Beaulieu D, Tsao H, Halpern AC, Michaud DS, Shaykevich S, et al. The first 30 years of the American academy of dermatology skin cancer screening program: 1985-2014. J Am Acad Dermatol. 2018; 79: 884-91. PubMed PMID: 30057360.

17. Rustad AM, Lio PA.. Pandemic pressure: teledermatology and health care disparities. JPatient Exp. 2021; 8:2374373521996982. PubMed PMID: 34179385.
18. Conic RZ, Cabrera Cl, Khorana AA, Gastman BR. Determination of the impact of melanoma surgical timing on survival using the National Cancer Database. J Am Acad Dermatol. 2018; 78 (1): 40-46.e7. PMID: 29054718.

19. American Cancer Society. Cancer Facts and Figures. January 8, 2021. Available from: https://www.cancer.org/content/dam/ cancerorg/research/cancer-facts-and-statistics/annual-cancerfacts-and-figures/2020/cancer-facts-and-figures-2020.pdf.

20. Farr MA, Duvic M, Joshi TP. Teledermatology during COVID-19: an updated review. American Journal of Clinical Dermatology. 2021; Apr 9: 1-9. PubMed PMID: 33835345.

21. Perkins S, Cohen JM, Nelson CA, Bunick CG. Teledermatology in the era of COVID-19: experience of an academic department of dermatology. Journal of the American Academy of Dermatology. 2020; 83 (1): e43-e44. PubMed PMID: 32305442.

22. Ashique KT, Kaliyadan F. Teledermatology in the wake of COVID-19 scenario: An Indian perspective. Indian Dermatology Online Journal. 2020; 11 (3): 301. PubMed PMID: 32695684.

23. Boyers LN, Schultz A, Baceviciene R, Blaney S, Marvi N, Dellavalle $\mathrm{RP}$, et al. Teledermatology as an educational tool for teaching dermatology to residents and medical students. Telemedicine and e-Health. 2015; 21 (4): 312-4. PubMed PMID: 25635528.

24. Wanat KA, Newman S, Finney KM, Kovarik CL, Lee I. Teledermatology education: current use of teledermatology in US residency programs. J Grad Med Educ. 2016; 8 (2): 286-7. PubMed PMID: 27168912.

25. Jones VA, Clark KA, Puyana C, Tsoukas MM. Rescuing medical education in times of COVID-19. Clin Dermatol. 2021; 39(1): 33-4.

26. Tensen E, Van Der Heijden JP, Jaspers MWM, Witkamp L. Two decades of teledermatology: current status and integration in national healthcare systems. Curr Dermatol Rep. 2016; 5 (2): 96-104. PubMed PMID: 27182461.

27. Tschandl P, Rinner C, Apalla Z, Argenziano G, Codella N, Halpern $A$, et al. Human-computer collaboration for skin cancer recognition. Nature Medicine. 2020; 26 (8): 1229-34. PubMed PMID: 32572267. 